\title{
PENERAPAN METODE KANO \\ DALAM ANALISIS TINGKAT KEPUASAN MAHASISWA TERHADAP PENEREPAN SISTEM INFORMASI AKADEMIK BERBASIS WEB
}

\author{
Ellbert Hutabri \\ Program Pendidikan Informatika STKIP PGRI Sumbar \\ ellbert.hutabri@gmail.com
}

\begin{abstract}
Academic information system is designed for data processing purposes academic. With the advanced information technology academic process can be managed into useful information in the Management college and decision making for top management in the college environment. Academic information system can be presented in the form of a website. Which contains features related to academic purposes. To see the effectiveness of the use of the website needs to be held evaluation. Evaluation can be done by measuring the level of user satisfaction to the features presented. The level of satisfaction can be measured with Kano method. Kano method is a method that aims to categorize the attributes of the products or services based on how well the product or service is able to satisfy its customers. This research is motivated by the use of web-based academic information system at the FKIP of University Muhammadiyah West Sumatra that does not satisfy the user. This study aimed to a) know how to Kano method in the application of the method to measure the level of student satisfaction, b) to determine student satisfaction toward web-based information systems academic using Kano, c) evaluating the lack of information systems in accordance with the needs of students, d) provide recommendations on UMSB management if there is dissatisfaction of students to academic web-based information systems. The results showed the level of satisfaction of students on the use of web-based information system as follows. First, there are two features in the website are in use is very satisfying for students. Secondly, six feature generates satisfied at the level of the student as user. Third, two features used students generate sufficient levels of satisfaction. Fourth, the features are less satisfied at the level of usage by students.
\end{abstract}

Keywords: students, Kano method, feature, system information, the website, the level of satisfaction.

\section{Latar Belakang}

Pelayanan sistem informasi akademik merupakan hal yang penting diperhatikan oleh setiap perguruan tinggi. Perguruan tinggi yang mampu memberikan layanan sistem informasi akademik maka akan mampu bersaing dengan berbagai perguruan tinggi lain baik tingkat lokal maupun nasional. Banyak cara yang dapat ditempuh untuk memaksimalkan layanan sistem informasi akademik di sebuah perguruan tinggi. Salah satunya dengan menggunakan layanan berbasis website. Pelayanan sistem informasi berbasis web sangat efektif karena dapat mengatasi permasalahan keterbatasan jarak dan waktu mahasiswa. Contohnya, mahasiswa yang berjarak tinggal jauh dari lokasi kampus tempat kuliah, dapat melakukan registrasi akademik melalui web. Hal ini membuktikan bahwa penerapan sistem informasi akademik berbasis web 
sangat menguntungkan dan mengefektifkan bagi mahasiswa.

Apabila layanan sistem informasi berbasis web telah diterapkan oleh perguruan tinggi, hal selanjutnya yang perlu dilakukan adalah mengevaluasinya. Tujuan evaluasi tersebut adalah untuk mengetahui persentase tingkat kepuasan mahasiswa terhadap penerapan web tersebut. Berbagai metode dapat diterapkan untuk mengukur tingkat kepuasan mahasiswa terhadap sistem informasi berbasis web, salah satunya adalah metode Kano.

\subsection{Perumusan Masalah}

Berdasarkan latar belakang, maka dalam penelitian ini dirumuskan sebagai berikut:

1. Bagaimanakah langkah mengukur tingkat kepuasan mahasiswa terhadap sistem informasi akademik berbasis web dengan menggunakan metode Kano?

2. Apakah parameter yang digunakan dalam mengukur tingkat kepuasan mahasiswa terhadap sistem informasi akademik berbasis web dengan menggunakan metode Kano?

\subsection{Batasan Masalah}

Berdasarkan

identifikasi

permasalahan maka penelitian ini dibatasi pada :

1. User yang diteliti adalah mahasiswa aktif pada semester yang sedang berjalan.

2. Atribut sistem informasi akademik yang dievaluasi merupakan layanan kepada mahasiswa.

\subsection{Tujuan Penelitian}

Penelitian ini bertujuan untuk :

1. Untuk mengetahui bagaimana penerapan metode Kano dalam mengukur tingkat kepuasan mahasiswa.
2. Untuk menentukan kepuasan mahasiswa terhadap sistem informasi akademik berbasis web dengan menggunakan metode kano.

3. Mengevaluasi kekurangan sistem informasi sesuai dengan kebutuhan mahasiswa.

4. Memberikan rekomendasi kepada pihak manajemen UMSB jika terdapat ketidak puasan mahasiswa terhadap sistem informasi akademik berbasis web.

\subsection{Manfaat Penelitian}

Penelitian diharapkan bermanfaat bagi :

1. Bagi UMSB; Untuk mengevaluasi penerapan sistem informasi akademik berbasis web yang telah ada.

2. Bagi peneliti lain; Hasil penelitian ini diharapkan bermanfaat sebagai referensi dalam melakukan penelitian sebidang.

3. Bagi mahasiswa jurusan sistem informasi; Hasil penelitian ini diharapkan dapat menjadi referensi dalam bidang sistem informasi.

\section{Landasan Teori}

Metode Kano dikembangkan oleh Noriaki Kano (Tony wijaya, 2011). Metode Kano adalah metode yang bertujuan untuk mengkategorikan atribut-atribut dari produk maupun jasa berdasrkan seberapa baik produk atau jasa tersebut mampu memuaskan kebutuhan pelanggannya.

Menurut Widian K (2004), metode kano adalah metode yang bertujuan untuk mengkategorikan atribu-atribut produk maupun jasa beradasarkan seberapa baik atribut tersebut mampu memuskankebutuhan pelanggan.

Implikasi dari model Kano adalah keinginan pelanggan lebih bersifat dinamis dari pada statis. Pada saat ini banyak beredar produk sesjenis yang dapat dipilih pelanggan, 
sehingga hanya produk inovatif yang dapat menarik perhatian pelanggan untuk dapat bertahan dalam persaingan yang ketat. Strategi yang dapat digunakan perusahaan dalam menghasilkan produk yang dapat melapui harapan pelanggan adalah dengan memproduksi produk yang mempunyai attractive quality. Strategi ini mengharuskan perusahaan memperhatikan bagaimana menciptakan attractive quality dalam proses pengembangan produk baru.

\subsection{Atribut Produk Menurut Metode Kano}

Atribut-atribut layanan dalam metode Kano dapat dibedakan menjadi beberapa kategori:

1. Must Be atau Basic needs.

Pada kategori keharusan (must be) atau kebutuhan dari (basic needs), pelanggan menjadi tidak puas apabila kinerja dari atribut yang bersangkutan rendah. Tetapi kepuasan pelanggan tidak akan meningkat jauh diatas netral meskipun kinerja dari atribut tersebut tinggi.

2. One-dimensional atau performance needs Dalam kategori one dimensional atau performance needs, tingkat kepuasan pelanggan berhubungan linear dengan kinerja atribut, sehingga kinerja atribut yang tinggi akan mengakibatkan tingginya kepuasan pelanggan pula.

3. Attractive atau excitement needs

Sedangkan pada kategori attractive atau excitement needs, tingkat kepuasan pelanggan akan meningkat sampai tinggi dengan meningkatnya kinerja atribut. Akan tetapi penurunan kinerja atribut tidak akan menurunkan tingkat kepuasan.

Ketidak tahuan terhadap atribut layanan dapat menimbulkan akibat negatif bagi pihak perusahaan. Harus diperhatikan pula bahwa kategori pelanggan tersebut tidak tetap sepanjang masa kategori pelanggan akan berubah sesuai dengan perkembangan waktu. Secara spesifik atribut attrctive akan menjadi one dimensional,dan akhirnya akan menjadi atribut must be.

Pada dasarnya pada model kano terdiri dari 3 tetapi respon konsumen selalu muncul kategori indefferent, questionable, dan reverse. Indefferent, kategori di mana jika ada tidaknya layanan tidak akan berpengaruh pada kepuasan konsumen. Reverse (kemunduran), Derajat kepuasan konsumen lebih tinggi jika layanan berlangsung tidak semestinya dibandingkan kepuasan terhadap layanan yang berjalan lebih baik., questionable (diragukan) Kadangkala konsumen puas Atau tidak puas jika layanan itu diberikan. Menurut Rashid (2010; 2) model Kano untuk kepuasan pelanggan dapat digambarkan seperti pada gambar 1.

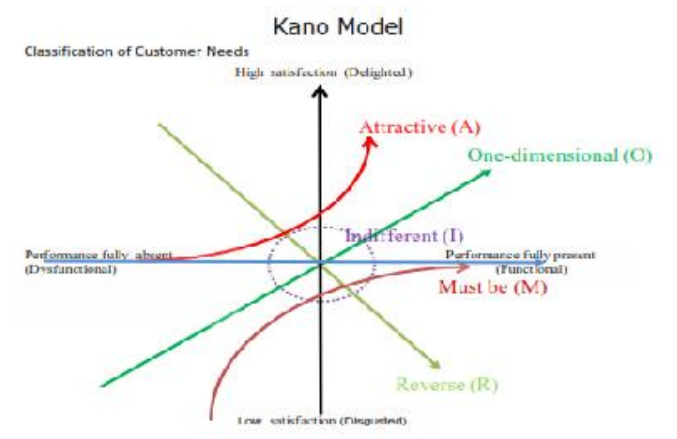

Gambar 1. Model Kano

\subsection{Keuntungan Metode Kano}

1. Prioritas untuk pengembangan produk. Sebagai contoh, sangatlah tidak berguna untuk melakukan investasi dalam peningkatan kategori must-be yang telah berada pada level memuaskan tetapi lebih baik meningkatkan kategori onedimensional atau attractive karena keduanya memiliki pengaruh yang lebih besar pada kualitas produk dan tingkat kepuasan konsumen. 
2. Product requirements lebih dipahami. Kriteria produk yang memiliki pengaruh paling besar pada kepuasan konsumen dapat diidentifikasi.

3. Model Kano untuk kepuasan konsumen secara optimal dapat dikombinasikan dengan quality function deployment. Merupakan sebuah syarat mutlak untuk mengidentifikasi customer needs, hirarki dan prioritasnya. Model Kano digunakan untuk menentukan importance dari feature produk secara individu untuk kepuasan konsumen dan menciptakan syarat mutlak yang optimal untuk orientasi proses pada aktivitas pengembangan produk.

4. Model Kano menyediakan bantuan yang berharga dalam situasi trade-off, dalam tahap pengembangan produk. Jika terdapat dua product requirements yang tidak dapat dipenuhi secara bersamaan karena alasan teknis atau finansial, kriteria tersebut dapat diidentifikasi dengan melihat mana yang memiliki pengaruh paling besar pada kepuasan konsumen.

5. Menemukan dan memenuhi attractive requirements akan menciptakan sebuah perbedaan yang sangat besar. Sebuah produk yang hampir memenuhi kepuasan akan kategori must-be dan onedimensional dipandang sebagai produk yang rata-rata dan oleh karena itu dapat digantikan dengan mudah. (Hinterhuber/Aichner/Lobenwein, 1994)

\subsection{Tahap Kerja Metode Kano}

Langkah-langkah penelitian dengan menggunakan Model Kano adalah :

1. Identifikasi ide/permintaan pelanggan atau menganalisa yang akan diukur.

2. Membuat Kuesioner Kano Dalam pembuatan Kuesioner yang perhitungannya menggunakan Model Kano maka sifat dari Kuisioner tersebut adalah setiap satu pertanyaan memiliki dua bagian yaitu functional dan disfunctional.

Dalam membuat pertanyaan, pertanyaan yang telah diuji terlebih dahulu validitas dan reliabilitasnya. Kelima variabel dalam Kano tersebut termasuk skala Likert, karena memiliki gradiasi dari sangat positif sampai sangat negatif.

Untuk setiap variabel tidak diberi skor dalam pengolahan datanya tetapi mengikuti langkah-langkah yang sesuai dengan Model Kano yaitu dengan menggunakan Tabel Evaluasi Kano pada Tabel 1.

3. Memproses hasil jawaban Kuisioner dengan menggunakan Tabulation of Surveys seperti terlihat pada Tabel 3, untuk memproses hasil jawaban Tabel Evaluasi Kano.

4. Menganalisa hasil proses. Langkah yang dilakukan dengan memposisikan setiap atribut pertanyaan.

\subsection{Pengertian Kepuasan}

Kata kepuasan (satisfactions) berasal dari bahasa latin "statis" (artinya cukup baik, memadai) dan "facio" (melakukan atau membuat), menurut Tjiptono dan Chandra (2004; 195) kepuasan bisa diartikan sebagai upaya pemenuhan suatu atau membuat sesuatu memadai.

Kepuasan adalah suatu keadaan yang dirasakan konsumen setelah dia mengalami suatu kinerja (atau hasil) yang telah memenuhi berbagai harapannya. Menurut Oliver, kepuasan adalah tingkat perasaan seseorang (pelanggan) setelah membandingkan antara kinerja atau hasil yang dirasakan (pelayanan yang diterima dan dirasakan) dengan yang diharapkannya (Irine, 2009, p.61).

\section{Pendekatan Penelitian}

Penelitian ini dilakukan dengan pendekatan kuantitatif. Penelitian kuantitatif, menurut Robert Donmoyer (dalam Given, 
2008: 713), adalah pendekatan-pendekatan terhadap kajian empiris untuk mengumpulkan, menganalisa, dan menampilkan data dalam bentuk numerik daripada naratif.

Menurut Cooper \& Schindler (2006: 229), riset kuantitatif mencoba melakukan pengukuran yang akurat ter-hadap sesuatu.

\subsection{Subjek Penelitian}

Dalam penelitian ini subjek penelitiannya adalah mahasiswa yang aktif pada Fakultas Keguruan dan Ilmu Kependidikan Universitas Muhammadiyah Sumatera Barat.

\subsection{Populasi dan Sampel}

Menurut Arikunto (2006, 134) Apabila subjek penelitian kurang dari 100, lebih baik diambil semua sehingga penelitiannya merupakan penelitian populasi. Tetapi, jika subjeknya besar, dapat diambil antara $10-15 \%$ atau $20-25 \%$ atau lebih. Karena subjek penelitian lebih dari 100 orang maka digunakan $15 \%$.

\subsection{Instrumen Penelitian}

Instrumen merupakan alat yang digunakan untuk melakukan sesuatu. Sedangkan penelitian memiliki arti pemeriksaan, penyelidikan, kegiatan pengumpulan, pengolahan, analisis dan penyajian data secara sistematis dan objektif. Dengan masing-masing pengertian kata tersebut di atas maka instrumen penelitian adalah semua alat yang digunakan untuk mengumpulkan, memeriksa, menyelidiki suatu masalah, atau mengumpulkan, mengolah, menganalisa dan menyajikan datadata secara sistematis serta objektif dengan tujuan memecahkan suatu persoalan atau menguji suatu hipotesis. Jadi semua alat yang bisa mendukung suatu penelitian bisa disebut instrumen penelitian. Instrumen penelitian digunakan untuk mengukur nilai variabel yang diteliti. Instrumen dalam penelitian ini adalah denga menyebarkan kusioner kepada mahasiswa FKIP UMSB.

Arikunto $(2006 ; 151)$ kusioner adalah sejumlah pernyataan tertulis yang digunakan untuk memperoleh informasi dari responden dalam arti laporan tentang dirinya, atau halhal yang ia ketahui.

Adapun keuntungan menggunakan kusioner adalah:

1. Tidak memerlukan hadirnya peneliti.

2. Dapat dibagikan secara serentak kepada responden.

3. Dapat dijawab oleh responden menurut kecepatannya masingmasing dan menurut waktu senggang responden.

4. Dapat dibuat anonym sehingga responden bebes, jujur dan tidak malu-malu menjawab.

5. Dapat dibuat terstandar sehingga bagi semua responden dapat diberi pertanyaan yang benar-benar sama.

\section{Teknik Analisis Data}

Didalam menganalis data metode Kano terlebih dahulu harus mengklasifikasikan atribut layanan, yaitu:

1. Menentukan kategori atribut tiap responden

Untuk menentukan atribut layanan dalam metode Kano, langkah pertama adalah menentukan jawaban keseluruan atas kuesioner responden berdasarkan pengelompokan pertanyaan dari functional dan dysfunctional question. Lihat Tabel 1.

Penentuan kategori Kano untuk setiap atribut dengan menggunakan Blauth's Formula adalah sebagai berikut: (Pawitra, 2002)

a. Jika (one-dimensional + attractive + must-be) > (indifferent + reverse + questionable), maka grade diperoleh dari ujung yang paling maksimum dari (onedimensional, attractive, must-be). 
b. Jika (one-dimensional + attractive + must-be $)<$ (indifferent + reverse + questionable), maka grade diperoleh dari ujung yang paling maksimum dari (indifferent, reverse, questionable).

Alasan menggunakan metode formula ini adalah karena pada dasarnya Model Kano terdiri dari tiga kategori yaitu attractive, one-dimensional, dan must be. Akan tetapi dalam respon konsumen selalu ada dan muncul kategori indifferent, reverse, dan questionable.

2. Menghitung jumlah masing-masing katetogri Kano dalam tiap-tiap atribut.

Setelah mengkombinasikan jawabanjawaban responden berdasarkan pertanyaan fungsional dan disfungsional, hasil dari evaluasi Kano tersebut dimasukkan pada tabel hasil yang menunjukkan distribusi keseluruhan dari kategori customer requirements. Prosesnya dapat dilihat pada Gambar 2. (Sauerwein, F. Bailom, K. Matzler, \& H.H. Hinterhuber, 1996)

3. Menghitung tingkat kepuasan

Dari hasil perhitungan jumlah kategori-kategori tiap atribut diperoleh, maka dapat hitung koefisien kepuasan konsumen dengan rumusan:

a. Tingkat kepuasan

Koefisian tingkat kepuasan berkisar antara 0 sampai dengan 1, semakin dekat dengan nilai 1 maka semakin mempengaruhi kepuasan konsumen, sebaliknya jika nilai mendekati ke 0 maka dikatakan tidak begitu mempengaruhi kepuasan konsumen.

$$
\frac{A+O}{A+O+M+I}
$$

b. Tingkat Kekecewaan.

Jika nilai semakin mendekati angka -1 maka pengaruh terhadap kekecewaan konsumen semakin kkuat, sebaliknya jika nilainya 0 maka tidak mempengaruhi kekecewaan konsumen.

$$
\frac{O+M}{A+0+M+I \quad X(-1)}
$$

Tanda minus yang disimpan di depan koefisien tingkat kekecewaan konsumen adalah untuk menegaskan pengaruh negatif dari kepuasan konsumen pada kualitas produk yang tidak dipenuhi.

\subsection{Penggolahan Data}

Pengolahan data ini dilakukan setelah menyebarkan quesioner dan setelah selesai menyebarkan quesioner maka semua quesioner dikumpulkan dan ditabulasi datanya, data dinyatakan valid jika hitungan $r$ dihitung $>r$ tabel.

\subsection{Analisis Uji Validitas Data}

Setelah semua quesioner telah dikumpulkan dan dibuat tabulasi datanya maka dilakukan uji validitas untuk mengetahui apakah masing-masing item pertanyaan dapat dinyatakan valid dengan menggunakan software SPSS versi 16.0 dan dapat dipakai untuk dilakukan analisis lebih lanjut atau tidak. Item pertanyaan dinyatakan valid jika $r$ hitung $>r$ tabel dan dinyatakan tidak valid jika pertanyaan $r$ hitung $<r$ tabel.

Skala yang digunakan adalah dengan menyediakan tiga sampai lima alternative jawaban menurut skala Likert adalah 1 sampai 4

Dalam peneltian ini menggunakan teknik analisis butir dengan uji coba 59 responden, kemudian mengkorelasikan skor butir dengan skor total. Kaidah pepgambilan kesimpulan yaitu apabila $\mathrm{r}$ hitung $>\mathrm{r}$ tabel, maka butir angket tersebut valid, sedangkan apabila $r$ hitung < $r$ tabel, maka butir angket tersebut tidak valid. Dari perhitungan di atas yaitu $r_{x y}$ dikonsultasikan dengan $r$ tabel dengan $\mathrm{N}$ sebanyak 30 responden pada taraf signifikansi $5 \%$ nilai $r$ tabel $=0,266$. 


\section{Jurnal Edik Informatika \\ ISSN : 2407-0491 \\ E-ISSN : 2541-3716}

Penelitian Bidang Komputer Sains dan Pendidikan Informatika

V1.i1(55-63)

\subsection{Analisis Uji Reliabilitas Data}

Uji reliabilitas dilakukan dengan menggunakan reliability analysis yang terdapat pada SPSS for Windows versi 16.0

\subsection{Analisis Kano}

Analisis dalam penelitian ini menggunakan metode kano adalah dengan menggunakan survey dengan cara mengambil sampel dari suatu populasi dan menggunakan koesioner. Koesioner disebarkan dimana setiap pertanyaan mengandung penilai yaitu suka, mengharapkan, netral, toleransi dan tidak suka. Pertanyaan di pertanyakan dua kali kepada responden, dimana pertanyaan pertama bersifat positif dan pertanyaan kedua bersifat negatif( kebalikan).

Adapun langkah-langkah untuk mengklasifikasikan atribute berdasarkan metode kano adalah sebagai berikut:

1. Menentukan kategori artibut tiap responden berdasarkan tabel evaluasi metode kano sebagai berikut:

\section{Tabel 6. Evaluasi Metode Kano}

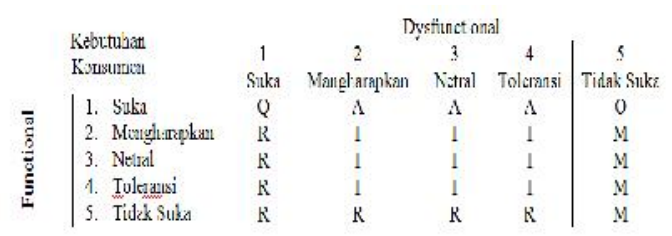

$\mathrm{O}$ : one dimensional requirement (satu ukuran)

A : Actractive requirement (menarik)

$\mathrm{I}$ :Indifferen requirement ( netral)

$\mathrm{R}$ : Reversal requirement (kemunduran)

Q : Questionable requirement (diragukan)

2. Menghitung jumlah masing-masing kategori kano dalam tiap-tiap atribut:
Setelah dilakukan perhitungan terhadap jawaban dari responden maka dilakukan perhitungan dan analisa penklasifikasian dari kategori kano maka diperoleh jumlah/ nilai dari kategori kano dari tiap-tiap atribut terhadap semua responden dapat diliha dari tabel 4.7:

\section{Tabel 7. Hasil Perhitungan Metode Kano}

\begin{tabular}{|c|c|c|c|c|c|c|c|c|c|}
\hline \multirow{2}{*}{ No } & \multirow{2}{*}{ Ldiku } & \multicolumn{6}{|c|}{ 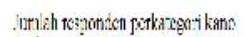 } & & \multirow{2}{*}{ G } \\
\hline & & 0 & A & Y & I & $\mathrm{R}$ & 0 & & \\
\hline & Fuassi T:mpilMateri Kulik: & 13 & 23 & $?$ & 3 & 1 & $?$ & 50 & A \\
\hline & 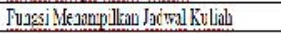 & 19 & 22 & 4 & 4 & 2 & 3 & 59 & A \\
\hline 3 & Fuscs Mescjukar Cout Koliab & 11 & 26 & 5 & $i j$ & 2 & $?$ & 59 & A \\
\hline & 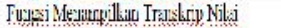 & 13 & 13 & 5 & 3 & 1 & Il & 59 & 0 \\
\hline & Fuges Poudaterer. Wisude: & 17 & 10 & $?$ & 10 & 2 & 4 & 50 & $A$ \\
\hline 6 & Fussi Cuatiog & 12 & II & 5 & 15 & 3 & 13 & 50 & I \\
\hline $\bar{t}$ & 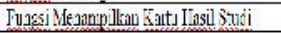 & 16 & 20 & 2 & $i$ & 3 & $?$ & 59 & $A$ \\
\hline 8 & 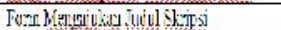 & 9 & 15 & 2 & 7 & $\delta$ & 19 & 59 & Q \\
\hline & 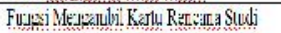 & 22 & 25 & 2 & 3 & iv & $?$ & D & 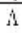 \\
\hline 10 & 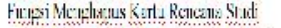 & 1 & \#1 & 5 & 6 & 2 & 1 & 59 & A \\
\hline 11 & 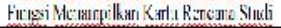 & 21 & 1.5 & 15 & 4 & 3 & 1 & 59 & 0 \\
\hline
\end{tabular}

Setelah menentukan requirement tertinggi dari masing-masing item, selanjutnya dilakukan perhitungan dari presentese dan extent of satisfaction dari tiaptiap item dengan menggunakan rumus sebagai berikut:

1. Menentukan Presentase

$$
\text { Presentase }=\frac{\text { Grade X } 100 \%}{\text { Total }}
$$

2. Menentuka Extent of Statisfaction

Extent of Statisfaction $=\frac{A+0}{A+0+M+I}$

3. Menentukan Extent of disstatisfaction

Enetent of Disstatisfaction $=\frac{O+M}{A+0+M+I x(-1)}$

Dari perhitungan diatas didapatkan nilai requirement yang akan menghasilkan nilai kepuasand an ketidak puasan terhadap penggunaan sistem informasi. 
Penelitian Bidang Komputer Sains dan Pendidikan Informatika

V1.i1(55-63)

\subsection{Grafik Defenisi Custumer Requirement}

Berdasarkan hasil perhitungan EoS dan EoD maka dapat dibuat grafik dengan gambar seperti berikut.

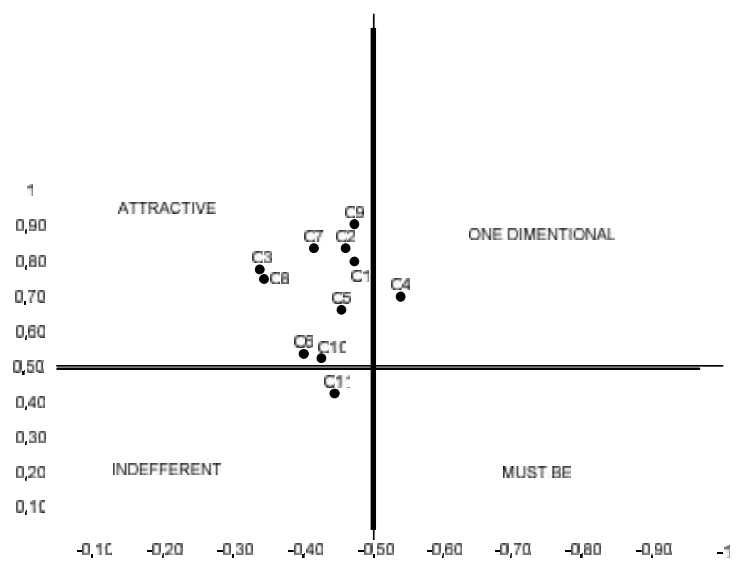

\section{Gambar 9. Diagram atribut Model Kano}

Dari tabel 7 di atas dapat dilihat setiap atribut dengan kategori dan tingkat kepuasan yang dirasakan oleh mahasiswa terhadap penggunaan sistem informasi akademik. Berdasarkan hasil resume dari tabel 4.9 maka kategori Kano untuk masingmasing atribut adalah seperti pada tabel 4.12.

\section{Tabel 4.12 Tingkat Kepuasan Untuk}

\begin{tabular}{|c|c|c|c|}
\hline $\mathrm{No}_{\mathrm{n}}$ & Atribut & Kategori Kano & Kequasan \\
\hline 1 & Fungsi Tampil Mater Ku hal & Atrract ve & nang \\
\hline 2 & 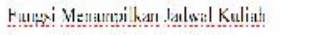 & Atrract ve & Sameat l'uas \\
\hline 3 & Enngei Vencainkan Cuti Kuliah & Aluractive & Pugs: \\
\hline 4 & 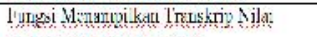 & One-dimentional & Phas \\
\hline 5 & Fungsi Pendattanan Visnda & Attract ive & Puas \\
\hline h & Fungsi Chotring & Indifleren1 & PIII: \\
\hline$?$ & 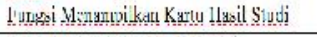 & istractive & SencatPuas \\
\hline 8 & Form Yengajukn Judul Skripsi & Questiousble & Pues \\
\hline 10) & Fungsi Henchapus Kartu Rencana Stndi & Atrract ve & Conluplyas \\
\hline 11 & 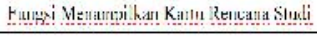 & Onc-diwcrulicanl & Kuraug $P_{\text {yls }}$ \\
\hline
\end{tabular}

\section{Kesimpulan}

Dari gambar 4.12 di atas dapat dilihat dengan jelas bahwa tingkat kepuasan pengguna tergantung pada tingkat koefisian kepusan berkisar antara 0 sampai dengan 1, semakin dekat dengan nilai 1 maka semakin mempengaruhi kepuasan mahasiswa, sebaliknya jika mendekati ke 0 maka tidak begitu mempengaruhi kepuasan mahasiswa.

Sedangkan tingkat kekecewaan dilihat dari nilai excent of dissatification. Jika nilai semakin mendkati angka -1 maka pengaruh terhadap kekecewaan mahasiswa semakin kuat, sebaliknya jika nilainya 0 maka tidak mempengaruhi kekecewaan mahasiswa.

Menurut Aditiawarman dalam Amran dan Ekadeputra (2000) kriteria tingkat kepuasana dalah : 0,00 - 0,34 Tidak puas; $0,35-0,50=$ Kurang puas; $0,51-0,65=$ Cukup puas; $0,66-0,80=$ Puas; $0,81-1,00$ $=$ Sangat puas.

Dari kriteria di atas dapat disimpulkan bahwa pada mahasiswa merasa paling puas pada fungsi pengambilan Kartu Rencana Studi (KRS) yaitu dengan tingkat tingkat kepuasan 0,90. Dan pada fungsi melihat dan menghapus KRS pada halaman yang berbeda mahasiswa merasa kurang puas yaitu dengan tingkat kepuasan 0,52 dan 0,41.

\section{Saran}

Dengan tingkat kepuasan yang rendah maka direkomendasikan kepada pihak manajemen untuk menghapus atau mengganti fungsi menghapus dan melihat krs hanya dalam satu fungsi saja.

\section{Daftar Pustaka}

Arikunto. 2006. Metode Penelitian; Aneka cipta, jakarta; Andi

Barmawi. Mira Musriani dan Dailami. 2013. The Implementation Of Kano Method for Definding Fitures In Infromation System of food Inventory. International Conference of Organizational Innovation 
Bauk, Sanja, Dkk. 2014. Estimating Students' Satisfaction with Web Based Learning System in Blended Learning Environment; Hindawi Publishing Corporation Education Research International.

Cahyana, Rinda. 2014. The Service Candidate Modelling of Academic Information Channel by Appliying of Service Oriented-Architecture;

Cooper, Donald R. dan Pamela S. Schindler. 2006. Metode riset bisnis, vol. 1, edisi 9(Business research methods, 9th edition); Jakarta: Media Global Edukasi

Edwar, Kridanto S.” Adopsi Metode Kano Untuk Kesuksesan Dan Ketidaksuksesan Sistem Informasi.

Given, Lisa M. (editor). 2008. The Sage encyclopedia of qualitative research methods. Thousand Oaks: Sage.

Jogiyanto.HM. 1998. Analisis Dan Disain Sistem Informasi : Pendekatan Terstruktur Teori Dan Praktek Aplikasi Bisnis, Yogyakarta : Andi. 